\title{
Sick building syndrome as a result of poor indoor air quality in educational and residential buildings
}

\author{
Anna Lis ${ }^{1}$
}

\begin{abstract}
:
The main goal in the design, construction and operation of buildings should be to create a favourable environment for people. Properly selected material, construction and installation solutions allow for the creation of healthy buildings, while significantly reducing energy consumption and costs. Impact on health and methods to reduce exposure to indoor air pollution vary depending on the type of building and its intended use. The improvements should concern, first of all, proper formation of indoor air quality and the mitigation of existing exposures in the building and its surroundings.

The paper discusses the phenomenon of sick building syndrome and the impact of improper ventilation and poor air quality in rooms on the formation of the syndrome symptoms. The results of research on the condition of the interior environment of pre-school, school and indoor apartments located in a multi-family residential buildings are presented. The results of measurements of selected thermal parameters of the interior microclimate, i.e. air temperature and relative humidity as well as carbon dioxide concentration, are presented. Based on the conducted questionnaires the phenomenon of the sick building syndrome was assessed among room users. Carbon dioxide levels above 1000 ppm have been exceeded, especially in educational buildings. The respondents mainly complained about the deteriorating air quality with the passage of time indoors, irritation of the eyes and respiratory tract, as well as fatigue and headache.
\end{abstract}

\section{KEYWORDS:}

SBS; indoor microclimate parameters; IAQ; educational and multi-family building; $\mathrm{CO}_{2}$ concentration

\section{Introduction}

The cause of malaise and health problems are often factors present in the immediate environment of a person, i.e. in the environment in which he most often lives. People spend a significant part of their lives in closed rooms, and those inside them are constantly subjected to the effects of an artificially created microenvironment. The current development of technology allows for the creation of all required conditions inside rooms, related to such values of microclimate elements that would be perceived as comfortable by people exposed to their influence.

Indoor air quality problems have not been clearly accentuated when window leaks allow a steady flow of air to the rooms. However, conducted on a large-scale, restrictive energy-saving ativities related to the sealing of the building evenlope do not always take into account the proper condition of the interior environment. Excessive leaks are of course the cause of increased heat consumption for ventilation purposes and lowering the temperature in rooms, but insufficient or inadequate ventilation contributes to a constant deterioration of air quality in closed rooms $[1,2]$. Attempts to drastically limit the amount of air exchanged in the process of ventilating rooms in buildings due to the realization of the energy saving program led to the phenomenon of "sick building syndrome" [3-5]. Of course, people can adapt reasonably well to environmental

1 Czestochowa University of Technology, Faculty of Civil Engineering, ul. Akademicka 3, 42-218 Częstochowa, e-mail: anna.lis@pcz.pl, orcid id: 0000-0001-9497-5754 
conditions, however, long-term exposure to extreme environmental conditions may lead to a deterioration of well-being, health, and a reduction in mental and physical performance [4, 6-8].

The general conditions of the interior micro-environment and the shaping of the value of individual elements of the microclimate largely depend on the way the buildings operates. This is related to the purpose of individual groups of buildings and to the individual habits of people using them. Although the purpose of the building, in a certain sense, determines the specific behaviour of people inside, nevertheless a lot depends on the personal preferences of individual users (e.g. the intensity of airing the rooms).

The aim of the study was to link the condition of the indoor environment in educational and residential buildings with the symptoms characteristic of the sick building syndrome phenomenon reported by their users, which they identified with long-term stay inside these buildings. Efforts were made to identify differences or similarities between the quality of the interior microenvironment in these buildings and its impact on the occurrence of sick building syndrome symptoms among people staying inside the rooms.

\section{Ventilation problems, indoor air quality and the sick building syndrome}

According to the World Health Organization, the term Sick Building Syndrome (SBS) refers to buildings in which at least $20 \%$ of users associate their malaise with staying inside for a long time. Staying in such a building causes and then intensifies many symptoms related to the malfunctioning of the body, leading to its weakness or disease. Disease symptoms that appear and worsen only during the stay in the building, and decrease or disappear after leaving the building are called symptoms of the syndrome $[4,9,10]$. These symptoms primarily include general malaise, irritability, permanent feeling of fatigue and sleepinees as well as problems with concentration, dizziness and headaches, irritation of the eyes, nose and throat, skin allergies, allergy-like symptoms, such as sneezing, problems with the respiratory and digestive systems, and in extreme cases with the nervous system. They are also referred to as Building Related Illness (BRI). These ailments are closely related to improper environmental conditions inside rooms and their insufficient ventilation $[2,11]$.

With the most commonly used gravity ventilation system in Poland, problems with ventilation were first caused by the use of increasingly tight windows with a low infiltration rate, which limited the inflow of air into the rooms. The air infiltration coefficient "a" is the amount of air that will penetrate in 1 hour through 1 meter of a slot in the window or balcony door at a pressure difference of $1 \mathrm{daPa}$. Windows production since 2009 should have an infiltration rate no greater than $0.3 \mathrm{~m}^{3} /\left(\mathrm{m} \times \mathrm{h} \times \mathrm{daPa}^{2 / 3}\right)$, but the legal regulation was introduced requiring the use of additional air supply unit. Providing effective ventilation is the first step to eliminating SBS. An alternative to the inadequate, for various reasons, gravity ventilation is mechanical ventilation, but here it is very important to keep the air supply elements clean, as the ventilation systems have ideal conditions for the growth of bacteria, mold and fungi.

Essential factors are: the way of using the rooms, selection of building materials and interior design elements. Increased air temperature and humidity cause the additional release of more chemicals stored in the finishing materials [7,12-14]. Indoor air quality is also influenced by people using the room. They are the source of the various elements. The presence of people and their activity in the room naturally increases the concentration of $\mathrm{CO}_{2}$ exhaled. The dynamics of this growth depends on the number of people and their individual characteristics, duration of stay, type of activity and air exchange in the room, as well as the size of the room. The amount of $\mathrm{CO}_{2}$ exhaled by people for different types of activities is shown in Table 1.

It is understood that the carbon dioxide content in a room should not exceed $1000 \mathrm{ppm}$. The content of carbon dioxide in clean atmospheric air is about 350-450 ppm. At the level of $2000 \mathrm{ppm}$, poor air quality and sleepiness is observed. At values of 2,000-5,000 ppm, headaches are possible. Values above 5,000 ppm lead to discomfort and a rapid heart rate, above $15,000 \mathrm{ppm}$, respiratory problems occur, and over $30,000 \mathrm{ppm}$, dizziness and indisposition. The concentration of the above 60,000 can cause death [15-18]. 
Table 1

The amount of $\mathrm{CO}_{2}$ exhaled by people (based on different sources and own studies)

\begin{tabular}{|l|l|l|l|l|l|l|l|}
\hline \multirow{3}{*}{ Types of activities } & \multicolumn{6}{l}{ Air temperature $\left[^{\circ} \mathrm{C}\right]$} \\
\cline { 2 - 8 } & 18 & 20 & 22 & 23 & 24 & 25 & 26 \\
\cline { 2 - 8 } & Amount of $\mathrm{CO}_{2}\left[\mathrm{dm}^{3} / \mathrm{h}\right]$ \\
\hline Rest & 10 & 10 & 11 & 11 & 12 & 13 & 13 \\
\hline Light work & 22 & 22 & 24 & 24 & 26 & 27 & 27 \\
\hline Medium hard work & 39 & 39 & 40 & 41 & 42 & 42 & 42 \\
\hline
\end{tabular}

A serious problem affecting indoor air quality is, especially in the heating season, significant outdoor air pollution and the lack of filtration in the room ventilation process $[19,20]$. A report by the WHO suggests that outdoor air pollution is the leading environmental cause of premature deaths in Europe, and smog is indicated as the 11th cause of death in the world. According to both the European Environment Agency and the State Inspectorate for Environmental Protection, high concentrations of particulate matter PM2.5 and PM10 as well as benzo(a)pyrene are still recorded in Poland. Among the 50 most polluted PM2.5 cities of the Europe 36 are located in Poland, and the average annual concentration of benzo(a)pyrene exceeds the permissible norms even by $500 \div 600 \%$. These pollutants penetrate the supply air stream and additionally deteriorate the condition of the interior micro-environment.

Proper air quality in residential environments is particularly important in terms of proper regeneration of the body after a working day, as well as its impact on the quality of sleep and well-being the next day. The residential environment is often a place for sick or elderly people, who require particularly good air quality on a constant bases. Unfortunately, air quality is often poor and $\mathrm{CO}_{2}$ significantly exceeds recommendations in the case of gravity ventilation [21-23]. Educational buildings are, next to the home, an important environment in which children spend a long time. The influence of the environment on pre-school and school-age children is greater due to the greater sensitivity of their not yet fully formed organisms. The conducted research showed very poor air quality in educational rooms. There is also a high incidence of allergic diseases in children. Research has been conducted on the incidence of various types of allergies in relation to the response to the quality of the indoor environment in educational buildings. A gradual worsening of unfavourable symptoms of the disease in recent years has been observed. Ventilation rates in classrooms are often well below the minimum ventilation rates specified in the requirements $[8,24-26]$. The obtained results confirmed that the traditional ventilation systems for educational buildings, in the form of gravity ventilation, used in Poland, are not able to ensure proper microclimate conditions in such buildings. The carbon dioxide concentrations recorded in the tested rooms even exceeded the standards applicable to working environments in industrial plants [27-31]. An equally important aspect of the microclimate of the rooms is to ensure appropriate conditions for both mental and physical work. Appropriate indoor conditions have an impact not only on the ability or willingness to work, but also on its efficiency and quality.

Poor indoor environmental conditions in buildings can generate significant costs for individuals, employers and society. These costs result from reduced productivity, sickness absenteeism and direct medical costs. Estimates of the benefits of improving the quality of the indoor environment in the United States show that the potential annual savings and productivity gains could range from $\$ 29$ to $\$ 168$ billion, and reducing absenteeism would result in net savings of $\$ 400$ per employee per year, while in Europe this may result in an annual benefit of EUR 330 per employee [32].

\section{Indoor microclimate parameters and symptoms SBS - material and methods}

The study covered the environmental conditions inside several buildings located in Częstochowa and the state of well-being and health of people staying in them. The analysis was carried out on the basis of measurements, questionnaires and observations. The research was carried out in several pre-school and primary school buildings, as well as, in a multi-family residential 
building. The research in pre-school buildings was carried out during the heating season and in the summer period. The research was carried out in rooms where children and their teachers spend most of the time in pre-school building. The rooms were situated on the ground floor and on the first floor. Research in school buildings was carried out during the heating season. The research was carried out in classrooms where pupils and their teachers reside. The classrooms were situated on the ground floor and on the first floor. Research in a multi-family residential buildings was carried out during the heating season and beyond. Measurements were made in the family room of the apartments, which is intended for general use by all residents. The apartments were situated on the first and second floors.

All the rooms where the research was conducted were rectangular in shape with windows on one of the long sides. In the apartments, windows were on the eastern elevation, in pre-school on the southern elevation and the primary schools on the west and south elevations. All rooms were equipped with gravity ventilation, the ventilation ducts were unobstructed. Windows in all rooms were plastic with a declared infiltration coefficient higher than $0.5 \mathrm{~m}^{3} /(\mathrm{m} \times \mathrm{h} \times \mathrm{daPa} / 3)$, which should determine the value of air inflow to the rooms. The stream of external air flowing into the rooms through $1 \mathrm{~m}$ of the window slots length at different values of the air infiltration coefficient "a" and the pressure difference on both sides of the window is shown in Figure 1.



Fig. 1. The external air inflow to the rooms at different values of "a" and pressure difference on both sides of the window

Environmental parameters were measured with calibrated instruments. In selected rooms, air temperature and relative humidity as well as carbon dioxide concentration were measured. The temperature measurement interval was from 0 to $60^{\circ} \mathrm{C}$, resolution is $0.1^{\circ} \mathrm{C}$ and accuracy $\pm 0.6^{\circ} \mathrm{C}$. The relative humidity range is 0.1 to $99.9 \%$. The relative humidity resolution is $0.1 \%$ and accuracy $\pm 3 \%$. The indoor air quality monitor measures $\mathrm{CO}_{2}$ levels in the range from 0 to $9,999 \mathrm{ppm}$, the resolution is $1 \mathrm{ppm}$, and accuracy $\pm 50 \mathrm{ppm}$ and $\pm 5 \%$ of reading. The devices were placed close to the center of the occupied area at a height of about one meter. The air temperature in the room was also measured at the head and feet level of the room users.

Information was collected on the people who use the rooms for long periods time, including the number of people (adults and children, male and female), as well as their age. The relationship between personal and environmental factors and SBS symptoms was investigated using developed questionnaires.

\section{The quality of the interior environment and symptoms of SBS among users - results and discussion}

The thermal elements of the interior microclimate have the strongest direct impact on the human body. However, extremely important for the proper functioning of the human body are also non-thermal elements, e.g. air pollution. 


\subsection{Pre-school buildings}

Prefabricated technology dominates among typical pre-school buildings. The buildings are characterized by a south-northern location. The administrative and economic part is located in the northern part. The rooms are located in the southern part of the building. In the examined pre-school buildings there were on average 5 rooms with an area of $56.3 \mathrm{~m}^{2}$ and a cubature of $180.2 \mathrm{~m}^{3}$. The buildings were characterized by significant glazing of the façades in the rooms, on average $48 \%$, the maximum value of glazing was $70 \%$. The rooms, in which the children stay, should be provided with a constant and efficient air exchange of at least $15 \mathrm{~m}^{3}$ per hour per one child and $20 \mathrm{~m}^{3}$ per hour per teacher.

The typical working time of the pre-school is from 6 AM to $4 \mathrm{PM}$. Children can stay in kindergarten for up to 10 hours a day. The duration of the child's stay in the room is on average 6-8 hours. The pre-school unit usually consists of 25 children. In the rooms where the measurements were carried out, there were on average 19 children in the summer season and 21 in the heating season, and 1 or two teachers. The teachers are women aged 35 on average, weight $64 \mathrm{~kg}$, height $162 \mathrm{~cm}$. Among the children, about $53 \%$ of the respondents were girls, the average age of the child was 5.9 years, the average weight was $23 \mathrm{~kg}$, height was $115 \mathrm{~cm}$ (girls) and $117 \mathrm{~cm}$ (boys). The estimated value of metabolism in adults was $1.4 \mathrm{met}$, and in children the average value was 2.3 met.

The average air temperature in pre-school rooms in the summer period remained at the level of $23.0^{\circ} \mathrm{C}$ with the standard deviation equal to $4.1^{\circ} \mathrm{C}$. During the heating season it was on average about $2.6^{\circ} \mathrm{C}$ lower, with the standard deviation equal to $3.4^{\circ} \mathrm{C}$. The temperature difference between the level of the head and the feet did not exceed $1.2^{\circ} \mathrm{C}$. Relative air humidity in the rooms in the summer period was on average at the level of $54 \%$ with the standard deviation equal to $9 \%$, and in the heating season at the average level of $30 \%$ with the standard deviation equal to $11 \%$. Measurements of carbon dioxide concentration in the rooms were carried out to a limited extent. The recorded levels remained at a fairly high level, on average in the range of $1382 \div 2328 \mathrm{ppm}$. The maximum value recorded was $3520 \mathrm{ppm}$. During the day, the classrooms were intensively ventilated several times, then the concentration of carbon dioxide dropped to the level of about $550 \mathrm{pm}$. With the help of teachers and using the jointly developed questionnaires adapted to the age level of the children, as well as on the basis of the author's own observations, the frequency of occurrence of specified ailments from the group of SBS symptoms in people staying in the rooms was noted. Also evaluated was the overall indoor air quality. The percentage occurrence of certain types of symptoms in the surveyed group of people staying in the pre-school rooms is presented in Figure 2.



Fig. 2. Percentage of occurrence the sick building syndrome symptoms in pre-school rooms (own research) 
During the heating season, the symptoms of eye irritation (approximately $34 \%$ of the respondents), nose (approximately 32\% of respondents) and throat (approximately 36\% of respondents), headache (approximately $41 \%$ of respondents), as well as fatigue and sleepinees (approximately 49\%) intensified. In the summer period, the symptoms of the syndrome generally decreased, general malaise (approximately 33\% of respondents), problems with concentration (approximately 39\% of respondents) and irritability (approximately 32\% of respondents) were noted more often. Bad air quality was, next to overheating rooms and noise, the most frequently signaled cause of discomfort experienced by adults staying in the pre-schools. The lack of sufficient ventilation of the rooms throughout the year was reported by as many as $85 \%$ of the respondents. During the heating season, this number increased to $97 \%$. Persistent health dysfunctions from the group of symptoms of sick building syndrome, in people staying indoors during the heating season, were primarily associated with poor air quality and insufficient ventilation, and thus with a high level of carbon dioxide. In the summer season, frequent opening of the windows significantly improved indoor air quality, but the problem was, with the significant glazing of the facade, overheating of the rooms, which resulted in general malaise, fatigue and problems with concentration.

The introduction of an automatically controlled ventilation system in the pre-school buildings would ensure a constant, gradual inflow of fresh air in the amount necessary to ensure appropriate hygienic and health conditions without the need to leave the rooms for the time of airing or stay in the zone of the flow of cold air stream with increased velocity, especially during the heating season.

\subsection{School buildings}

The school buildings, in which the research was carried out, were made in the prefabricated or traditional brick technology, as two-storey, with complete basement. There were general and specialist classrooms in the school buildings as well as auxiliary rooms (cloakrooms, administrative rooms, kitchen, canteen, common room, library, etc.). The average area of the classroom was $59.2 \mathrm{~m}^{2}$, and the cubic capacity was $184.6 \mathrm{~m}^{3}$. The rooms in which pupils stay should be provided with a constant, efficient air exchange in the amount of at least $20 \mathrm{~m}^{3}$ per hour, per one student and one teacher. In the absence of mechanical ventilation, the windows should have a structure that allows at least $50 \%$ of the area to be opened.

Lessons at school start at $8 \mathrm{AM}$, and the common school room is open from $7 \mathrm{AM}$ to $5 \mathrm{PM}$. The length of stay of children in school depends on the number of lessons on a given day provided for in the weekly school timetable. Early school education pupils (pupils in grades 1-3) spend the whole day at school usually in one room, the other pupils change rooms in which they study depending on the nature of the lessons provided in the school program. During breaks in the lessons, pupils usually spend time outside the classroom. Pupils may stay at school on average from 5 to 8 hours a day. In early school education groups there were a maximum of 25 pupils, and in the remaining groups - 35 pupils. In the rooms where the measurements were performed, there were on average 21 pupils and 1 teacher. The teachers are women aged 44 on average, weight $68 \mathrm{~kg}$, height $166 \mathrm{~cm}$. Among the children, approximately $67 \%$ of the respondents were girls, the average age of the child was 10.8 years, the average weight was $33 \mathrm{~kg}$, height was $139.6 \mathrm{~cm}$ (girls) and $143.3 \mathrm{~cm}$ (boys). The metabolic rate in adults was estimated to be $1.4 \mathrm{met}$, and in children an average of 1.6 met. The concentration of $\mathrm{CO}_{2}$ in the classrooms changed dynamically. The initial $\mathrm{CO}_{2}$ content in the air was around $500 \div 700 \mathrm{ppm}$ and it increased rapidly depending on the number of people in the rooms. Within an hour, this increase averaged $500 \div 600 \mathrm{ppm}$, and even $1000 \div 1100 \mathrm{ppm}$. The highest measured value was $3572 \mathrm{ppm}$. During school breaks, the rooms were ventilated intensively, then the concentration of carbon dioxide dropped to the level of about $350 \div 500 \mathrm{ppm}$. During the study, the frequency of ailments from the group of SBS symptoms was noted in people staying in the rooms. Overall indoor air quality was also evaluated. The percentage occurrence of SBS symptoms in the surveyed group of people staying in the school rooms is presented in Figure 3. 


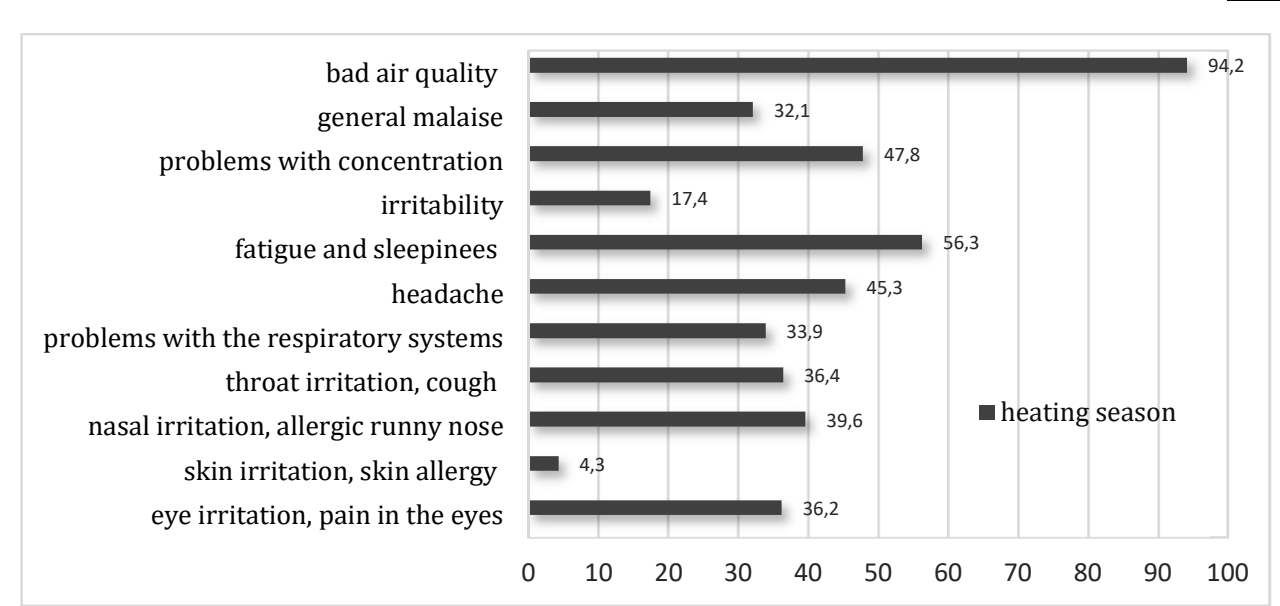

Fig. 3. Percentage of occurrence of sick building syndrome symptoms in school rooms (own research)

Users mainly mentioned increased eye (approximately $36 \%$ of respondents), nose (approximately $40 \%$ of respondents) and throat (approximately $36 \%$ of respondents) irritation, as well as problems with the respiratory systems (approximately 34\% of respondents). In classrooms, the greatest problems were noted with fatigue and sleepiness, headaches and difficulties in concentration, as well as generally deteriorating air freshness during the lesson. Poor air quality in rooms was indicated by $94 \%$ of people as the cause of general malaise. The main cause of this state of affairs should be looked for in the high concentration of carbon dioxide recorded in the school rooms.

During the heating season, the classroom environment was fairly similar to that of the preschool rooms, except that some symptoms of SBS were more severe in the school environment, perhaps due to the higher $\mathrm{CO}_{2}$ levels noted in classrooms. The use of classrooms is specific and results in a high demand for fresh air. There are almost always a large number of people in the classrooms who are required to stay there without the possibility of a break for long periods of time. Even in the case of underutilisation of the room we have to deal with the unfavorable relationship between the volume of the room and the number of its users. If there are 20 pupils in a classroom with an average volume of $180 \mathrm{~m}^{3}$, this means that only $9 \mathrm{~m}^{3}$ of air is available for each person. For a specific number of users and known room geometry, the necessary number of air changes should be determined and an automatically controlled inflow of pre-cleaned air should be introduced. Increasing the amount of indoor air exchange would reduce the level of $\mathrm{CO}_{2}$ pollution and greatly reduce the sick building phenomenon.

\subsection{Multi-family residential buildings}

The three and four-storey residential buildings with full basement were built in traditional brick technology. There are two, three and four-room apartments with a kitchen and a bathroom in the buildings. In individual apartments, research was carried out in the living room - a room intended for the common stay of users, for rest and recreation. The average area of the room was $19.8 \mathrm{~m}^{2}$, and the cubic capacity was $51.3 \mathrm{~m}^{3}$. There were two or three adults and one or two children among the users of the apartments. On average, the studied room housed 2-4 people, adults in the mean age of 46 and children in the mean age of 9.5. The estimated value of metabolism in adults was 1.4 mets, and in children the average value was 1.8 mets.

The average air temperature in the room in the summer period remained at the level of $24.1^{\circ} \mathrm{C}$ with the standard deviation equal to $3.1^{\circ} \mathrm{C}$. During the heating season, the average temperature was $22.2^{\circ} \mathrm{C}$ with the standard deviation equal to $1.8^{\circ} \mathrm{C}$. The temperature difference between the level of the head and the feet did not exceed $1.1^{\circ} \mathrm{C}$. Relative air humidity in the summer period was on average $51 \%$ with the standard deviation equal to $8 \%$, and in the heating season on 
average at $43 \%$ with the standard deviation equal to $10 \%$. The value of humidity increased dynamically during work such as cooking or washing (drying laundry indoors). The recorded values of carbon dioxide concentration during the heating season remained in the range of $1125 \div 1230 \mathrm{ppm}$. The maximum value recorded was $2,176 \mathrm{ppm}$. During the intensive airing of the room, the concentration of carbon dioxide dropped to a level below $350 \mathrm{ppm}$. In the spring period (outside the heating season), with the windows closed, the $\mathrm{CO}_{2}$ concentration remained on average in the range of $970 \div 1095 \mathrm{ppm}$.

In residential buildings, the majority of respondents assessing their state of well-being in relation to long-term stay in a given environment were adults. The general indoor air quality and the frequency of ailments from the group of symptoms of a sick building were assessed. The percentage occurrence of sick building syndrome symptoms in the surveyed group of people staying in the school rooms is presented in Figure 4.

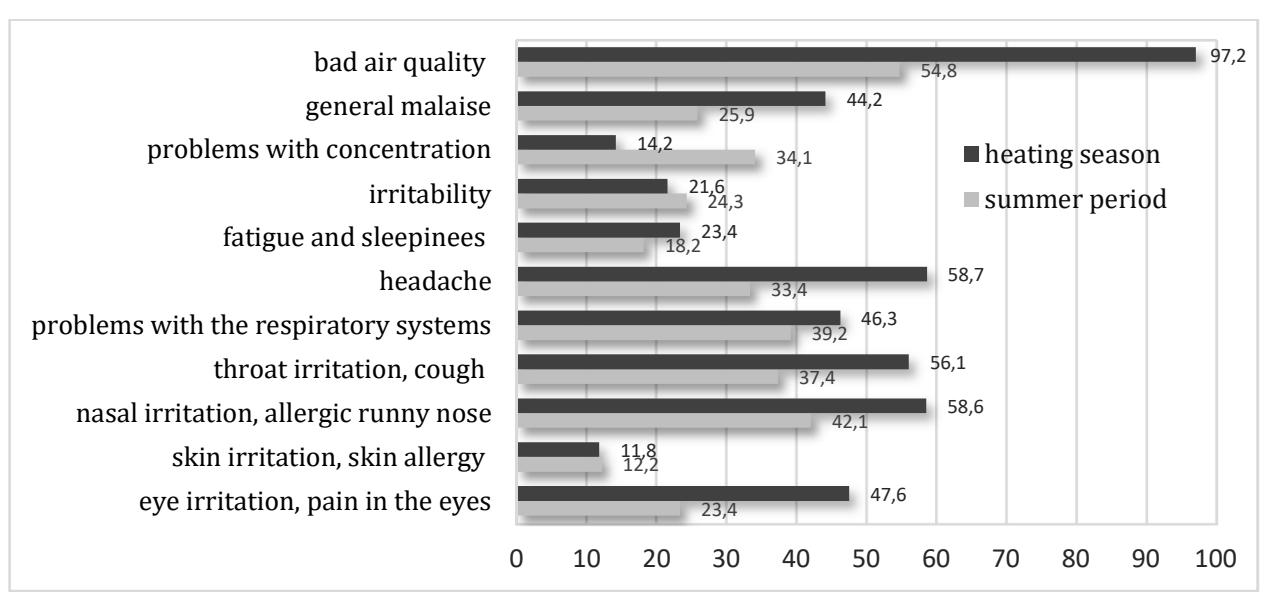

Fig. 4. Percentage of occurrence of sick building syndrome symptoms in residential buildings (own research)

Similarly to the environment of educational buildings, apartment users reported a general poor indoor air quality, especially in the heating season with the windows closed, as well as insufficient room ventilation and the need to open windows, which led to room cooling. The impossibility of airing the rooms in the evening hours and at bedtime was also signaled due to smog pollution which usually persisted outside during this period. A serious problem in residential buildings, which disrupts the proper operation of ventilation, is the lack of appropriate ventilation grills in the door between rooms with air supply and rooms with exhaust grills, as well as covering the ventilation grills. During the heating season, the respondents also reported the intensification of irritation symptoms in the eyes (about $48 \%$ of respondents), nose (about $59 \%$ of respondents) and throat (about 56\% of respondents), as in the environment of educational buildings. However, the severity of these symptoms was much higher than in educational buildings. General malaise (approximately $44 \%$ of respondents) and headache (approximately $59 \%$ of respondents) were also a problem. The occurrence of allergies in this period is associated mainly with low air humidity with simultaneously high air pollution, or with high humidity and the particularly dangerous development of mold and other microorganisms. Also, in the first case, with the emission of many harmful substances.

In the summer period, better air quality in rooms was indicated more clearly than in the heating season, as in educational buildings. During this period, windows in school buildings are open for a shorter period of time than in flats, due to external noise that interferes with learning. On the other hand, problems with concentration (about 34\% of respondents) and irritability (about 24\% of respondents) were noted more often. The syndromes reported during this period were also respiratory tract irritation (approximately 39\% of respondents), throat irritation and 
coughing (approximately 37\% of respondents), nose irritation and runny noses (approximately $42 \%$ of respondents), and headaches (approximately $33 \%$ of respondents).

In residential buildings, the values of carbon dioxide concentration were lower than in educational buildings. In a living room with a volume of $50 \mathrm{~m}^{3}$, each user has a larger air volume than in the rooms of educational buildings, on average $25 \mathrm{~m}^{3}$ for two people staying in the room and $12.5 \mathrm{~m}^{3}$ for four people. In addition, the rooms in the school and pre-school buildings are cut off from the rest of the rooms during the lessons, while in residential buildings the air exchange between rooms is usually free-flowing. This may have been the reason for the reduced frequency of some sick building syndrome symptoms in relation to the educational building environment. On the other hand, the intensification of some symptoms in the residential environment could be caused by the poor quality of the air infiltrating the rooms in the ventilation stream in the evening hours - the main use of these rooms by people of working age and children. The residential environment is also more exposed to contamination with certain substances than the environment of educational buildings, such as radon from gas combustion, substances from smoking or more frequently changed interior furnishings and equipment emitting non-ionizing radiation.

\section{Conclusions}

The environment in which a person resides should allow him to achieve a state of satisfaction with the conditions that prevail in him and fully satisfy his physical and mental needs. The shaping of certain conditions inside rooms has a significant impact on the health of people staying there, which, according to definition, is not only a disease-free state, but also a state of complete physical and mental well-being. Therefore, during the operation of buildings, ensuring proper indoor air quality seems to be a key problem. It is necessary to strive to create such optimal conditions inside the room so that each person feels satisfied with the environment in which they usually stay and that does not adversely affect their well-being and health. The quality of the environmental conditions in buildings intended for long-term stay of children is particularly important due to the incomplete formation of their organisms and greater sensitivity to the influence of the surrounding environment.

The basic function of ventilation is to provide the user with physiological comfort, i.e. an environment in which the concentration of gaseous pollutants and metabolic products will be maintained at an acceptable level. The long-term occurrence of poor air quality in rooms has led to the phenomenon of sick building syndrome, deterioration of well-being and the appearance of numerous disease symptoms among users of such rooms. Proper ventilation eliminates many health and utility problems (e.g. moldy partitions).

The importance of proper shaping of the interior environment of educational buildings also relates to the impact of these environments not only on well-being and health, but also on the educational process. Another element characteristic of educational rooms is the long exposure time, comparable to the working time of adults. In the rooms of educational buildings, the permissible level of $\mathrm{CO}_{2}$ concentration is often exceeded after about 20 minutes. Failure to meet hygiene requirements and the lack of fresh air has a significant impact on the well-being and concentration of physiologically sensitive children. Carbon dioxide concentration at the level $2000 \div 3000 \mathrm{ppm}$ do not ensure the safety of staying in the room. Poor air quality was the most commonly suggested cause of sick building symptoms by both residential and educational users. The most frequently reported symptoms were increased eye, nose and throat irritation and headaches. In the educational environment, children especially complained of fatigue, sleepiness and difficulty in concentrating. In school buildings, these symptoms were more severe. Increasing the amount of ventilated air exchange in the environment of educational buildings improves the children's efficiency in carrying out school tasks, improves their well-being, reduces health effects related to the impact of the environment and reduces absenteeism of pupils. This would be an effective way to reduce the incidence of SBS symptoms in a residential environment, necessarily taking into account measures to reduce outdoor air pollution entering the rooms. Increasing the flow of ventilated air increases the operating costs of buildings related to their 
heating, but they, for example, account for less than $0.1 \%$ of typical public expenditure on education, however, generate clear benefits for health and quality of science [25,33].

Due to the increase in morbidity, especially in children, and of various forms of allergies, which are a serious health problem for modern humanity, more and more attention is paid to the quality of the environment shaped indoors, especially in the era of stricter requirements in the field of thermal protection of buildings. Ensuring proper indoor air quality should be a priority in relation to energy saving measures $[26,34]$.

\section{References}

[1] Voznyak O., Myroniuk K., Sukholova I., Kapalo P., The impact of air flows on the environment, Proceedings of CEE 2019. Advances in resourse-saving technologies and materials in civil and environmental engineering, Ed.: Z. Blikharskyy, P. Koszelnik, P. Mesaros, Springer, Switzerland, 2019, 534-540.

[2] Müller J., Skrzyniowska D., Air quality and room ventilation, Czasopismo Techniczne 2012, 109(28), 37-49.

[3] Maddalena R., Mendell M.J., Eliseeva K., Chan W.R., Sullivan D.P., Russell M., Satish U., Fisk W.J., Effects of ventilation rate per person and per floor area on perceived air quality, sick building syndrome symptoms, and decision-making, Indoor Air 2015, 25(4), 362-70.

[4] Jafari M.J., Khajevandi A.A., Mousavi Najarkola S.A., Yekaninejad M.S., Pourhoseingholi M.A, Omidi L., Kalantary S., Association of sick building syndrome with indoor air parameters, Tanaffos 2015, 14(1), 55-62.

[5] Sarkhosh M., Najafpoor A.A., Alidadi H., Shamsara J., Amiri H., Andrea T., Kariminejad F., Indoor air quality associations with sick building syndrome: An application of decision tree technology, Building and Environment 2021, 188, 107446

[6] Al Horr Y., Arif M., Katafygiotou M., Mazroei A., Kaushik A., Elsarrag E., Impact of indoor environmental quality on occupant well-being and comfort: A review of the literature, International Journal of Sustainable Built Environment 2016, 5(1), 1-11.

[7] Wysocka M., DALY indicator as an assessment tool for indoor air quality impact on human health, E3S Web of Conferences 2018, 49, 00133.

[8] Haverinen-Shaughnessy U., Shaughnessy R.J., Cole E.C., Toyinbo O., Moschandreas D.J., An assessment of indoor environmental quality in schools and its association with health and performance, Building and Environment 2015, 9(1), 35-40.

[9] Boslaugh S.E., Sick building syndrome, Britannica, Apr 5, 2021, www.britannica.com

[10] Evolution of WHO air quality guidelines: past, present and future, WHO Regional Office for Europe, Copenhagen 2017.

[11] Kapalo P., Klymenko H., Voznyak O., Zhelykh V., Adamski M., Evaluating the state of sanitary and hygienic conditions in ventilated rooms, Theory and Building Practice 2019, 1(912), 63-67.

[12] Goldstein A.H., Nazaroff W.W., Weschler Ch., Williams J., How do indoor environments affect air pollution exposure? Environmental Science and Technology 2020, 55(1), 100-108.

[13] Müller J., Skrzyniowska D., Sikorska-Bączek R., Indoor Air Quality, Publishing Office of Cracow University of Technology, Cracow 2020.

[14] Godish T., Indoor Environmental Quality, Lewis Publishers, Boca Raton, London New York Washington 2016.

[15] Zhang X., Wargocki P., Lian Z., Thyregod C., Effects of exposure to carbon dioxide and bioeffluents on perceived air quality, self-assessed acute health symptoms and cognitive performance, Indoor Air 2017, 27(1), 47-64

[16] Mishra A.K., Schiavon S., Wargocki P., Tham K.W., Carbon dioxide and its effect on occupant cognitive performance: A literature review, Windsor Conference on Resilien Comfort Proceedings 2020, 432-444.

[17] Kapalo P., Domniţa F., Bacoţiu C., Spodyniu N., The impact of carbon dioxide concentration on the human health - case study, Journal of Applied Engineering Sciences 2018, 8(21), 61-66.

[18] Jayasooriya V.M., Rajapaksha R.M.D.H., Ng A.W.M., Muthukumaran S., Associations of indoor carbon dioxide concentration and symptoms of sick building syndrome in air-conditioned lecture halls, Research Square 2020, 1-29.

[19] Chanjuan S., Jialing Z., Yuchao G., Qingyan F., Wei L., Jun P., Yanmin H., Zhijun Z., Chena H., Outdoor air pollution in relation to sick building syndrome (SBS) symptoms among residents, Energy and Buildings 2018, 174, 68-76.

[20] Wysocka M., Examination of PM10 and PM2.5 concentration in an apartment in a multifamily building, Proceedings 2019, 16, 49.

[21] Gładyszewska-Fiedoruk K., Indoor air quality in the bedroom of a single-family house - A case study, Proceedings 2019, 16, 38.

[22] Bullová I., Kapalo P., Katunský D., Quantification of air rate change by selected methods in a typical apartment building, Biuldings 2021, 11, 174-194. 
[23] Kapalo P., Vilčeková S., Domnita F., Bacotiu C., Voznyak O., Determining the Ventilation Rate inside an Apartment House on the Basis of Measured Carbon Dioxide Concentrations - Case Study, 10th International Conference on Environmental Engineering Selected Papers, VGTU Press, Vilnius, 2017, 28-33.

[24] School environment: policies and current status, WHO Regional Office for Europe, 2015.

[25] Fisk W.J., The ventilation problem in schools: literature review, Indoor Air 2017, 27(6), 1039-1051.

[26] Langer S., Ekberg L., Teli D., Cabovska B., Bekö G., Wargocki P., Study of the measured and perceived indoor air quality in Swedish school classrooms, IOP Conference Series: Earth and Environmental Science 2020, 588, 032070 .

[27] Sowa J., Wentylacja klas szkolnych, EkoEnergia: ogrzewanie, wentylacja pomieszczeń, mądre budowanie, energia solarna, ekologia, Warszawa 2007.

[28] Sowa J., Noga-Zygmunt J., Ugorowska J., Indoor air parameters in higher education building before planned modernization to nZEB standard, Conference: Healthy Buildings 2017 Europe, Lublin 2017, 2.

[29] Turunen M., Toyinbo O., Putus T., Nevalainen A.,, Shaughnessy R., Haverinen-Shaughnessy U., Indoor environmental quality in school buildings and the health and wellbeing of student, International Journal of Hygiene and Environmental Health 2014, 217(7), 733-739.

[30] Kapalo P., Voznyak O., Klymenko H., Zhelykh V., Adamski M., Perception of air quality in the selected classroom, BoZPE 2019, 8(2), 77-84.

[31] Kapalo P., Voznyak O., Yurkevych Y., Myroniuk K., Sukholova I., Ensuring comfort microclimate in the classrooms under condition of the required air exchange, Eastern European Journal of Enterprise Technologies 2018, 5/10(95), 6-14

[32] Wargocki P., Productivity and Health Effects of High Indoor Air Quality, Encyclopedia of Environmental Health, Elsevier 2019, 382-388.

[33] Petersen S., Jensen K.L., Pedersen A.L.S., Rasmussen H.S., The effect of increased classroom ventilation rate indicated by reduced $\mathrm{CO}_{2}$ concentration on the performance of schoolwork by children, Indoor Air 2016, 26(3), 366-379.

[34] Lampi J. et al., Healthy people in healthy premises: The Finnish Indoor Air and Health Programme 2018-2028, Clinical and Translational Allergy 2020, 10(1), 4

\section{Syndrom chorego budynku jako rezultat złej jakości powietrza w pomieszczeniach budynków edukacyjnych i mieszkalnych}

\section{STRESZCZENIE:}

Głównym celem przy projektowaniu, wznoszeniu i eksploatacji budynków powinno być stworzenie środowiska przyjaznego dla człowieka. Odpowiednio dobrane rozwiązania materiałowo-konstrukcyjne i instalacyjne pozwalają na stworzenie zdrowych budynków, jednocześnie znacznie zmniejszając zużycie energii i koszty. Wpływ na zdrowie ludzi i metody ograniczania narażenia na zanieczyszczenie powietrza w pomieszczeniach różnią się w zależności od typu budynku i jego przeznaczenia. Ulepszenia powinny dotyczyć przede wszystkim prawidłowego kształtowania jakości powietrza w pomieszczeniach oraz łagodzenia istniejących narażeń w budynku i w jego otoczeniu. Omówiono zjawisko sick building syndrome oraz wpływ niewłaściwej wentylacji i złej jakości powietrza w pomieszczeniach na powstawanie symptomów syndromu. Zaprezentowano rezultaty badań dotyczących kondycji środowiska wnętrz budynków przedszkolnych, szkolnych oraz wewnątrz mieszkań znajdujących się w budynku mieszkalnym wielorodzinnym. Przedstawiono wyniki pomiarów wybranych termicznych parametrów mikroklimatu wnętrz, tj. temperatury i wilgotności względnej powietrza oraz stężenia dwutlenku węgla. Na podstawie przeprowadzonych ankiet dokonano oceny zjawiska syndromu wśród użytkowników pomieszczeń. Zanotowano przekroczony poziom stężenia dwutlenku węgla powyżej 1000 ppm, szczególnie w budynkach edukacyjnych. Respondenci skarżyli się przede wszystkim na pogarszającą się, z upływem czasu przebywania w pomieszczeniach, jakość powietrza oraz na podrażnienie oczu i dróg oddechowych, a także zmęczenie i ból głowy.

SŁOWA KLUCZOWE:

SBS; parametry mikroklimatu wnętrz; IAQ; budynki edukacyjne i wielorodzinne; stężenie $\mathrm{CO}_{2}$ 